\title{
ANALISIS FAKTOR-FAKTOR YANG MEMPENGARUHI RISIKO PRODUKSI USAHATANI PEPAYA DI KECAMATAN LEDOKOMBO KABUPATEN JEMBER
}

\section{ANALYSIS OF THE FACTORS THAT INFLUENCE THE PRODUCTION RISK OF PEPAYA FARMING IN THE SUB DISTRICT OF LEDOKOMBO, DISTRICT OF JEMBER}

Ganang Febriawan ${ }^{1}$, Syamsul Hadi ${ }^{2}$, Fefi Nurdiana Wijayanti ${ }^{2}$

1) Mahasiswa Program studi Agribisnis, Fakultas Pertanian, UM Jember

2) Dosen Program studi Agribisnis, Fakultas Pertanian, UM Jember e-mail: syamsulhadi@unmuhjember.ac.id

\begin{abstract}
ABSTRAK
Tingkat keberhasilan produksi tanaman pepaya dari pada jenis buah-buahan lain dapat ditentukan oleh produksi optimal yang dicapai oleh petani pepaya. Tercapainya produksi yang tinggi maupun rendah dapat menjadi dugaan indikasi yang menunjukan adanya faktor-faktor risiko produksi usahatani pepaya. Adanya risiko produksi berpengaruh terhadap hasil panen pepaya dan berimplikasi lebih lanjut terhadap pendapatan petani. Oleh karena itu, tujuan penelitian ini adalah untuk: (1) Mengidentifikasi pengaruh faktor-faktor internal dan eksternal terhadap risiko produksi usahatani pepaya; dan (2) Mengidentifikasi faktor-faktor yang mempengaruhi keuntungan usahatani pepaya. Penelitian ini dilaksanakan di Kecamatan Ledokombo Kabupaten Jember dengan menggunakan metode penelitian deskriptif dan data yang digunakan adalah data primer dan data sekunder. Pendekatan analisis data yang digunakan adalah pendekatan fungsi variance produktivitas dan fungsi keuntungan. Penelitian ini mengungkapkan bahwa: (1) Penggunaan faktor risiko produksi pupuk anorganik, tenaga kerja, pestisida padat, pestisida cair dan musim dapat meningkatkan risiko produksi pada taraf signifikansi 20\%, sementara di lain sisi bahwa penggunaan bibit, pupuk organik dan pupuk buah dapat menurunkan risiko produksi, tetapi berpengaruh tidak nyata terhadap usahatani pepaya. (2) Faktor produksi, harga jual, biaya tenaga kerja, biaya saprodi dan biaya lahan berpengaruh secara signifikansi $1 \%$, sedang-kan faktor musim berpengaruh tidak signifikan terhadap keuntungan usahatani pepaya.
\end{abstract}

Kata kunci: faktor risiko, variance produksi, keuntungan, pepaya.

\section{ABSTRACT}

The success rate of papaya production from other types of fruits can be determined by the optimal production achieved by papaya farmers. Achieving high and low production can be an indication that indicates the existence of risk factors for papaya farming production. The risk of production affects the yield of papaya and has further implications for farmers' income. Therefore, the purpose of this study is to: (1) Identify the influence of internal and external factors on the risk of papaya farming production; and (2) Identifying factors that influence the benefits of papaya farming. This research was conducted in Ledokombo Subdistrict, Jember Regency by using descriptive research methods and the data used were primary data and secondary data. The data analysis approach used is the approach to productivity variance functions and profit functions. This study revealed that: (1) The use of risk factors for inorganic fertilizer production, labor, solid pesticides, liquid pesticides and seasons can increase production risk at a significance level of $20 \%$, while on the other hand that the use of seeds, organic fertilizers and fruit fertilizers can reduce production risk, but no significant effect on papaya farming. (2) Factors of production, selling prices, labor costs, input costs and land costs have a significant effect of $1 \%$, while seasonal factors have no significant effect on the profitability of papaya farming.

Keywords: risk factors, production variance, profits, papaya. 


\section{PENDAHULUAN}

\section{Latar Belakang}

Pepaya (Carica pepaya L.) adalah salah satu tanaman yang habitat aslinya hutan tropis, tetapi dapat tumbuh subur dengan baik di daerah sub-tropis, daerah basah hingga kering ataupun dataran rendah maupun pegunungan dan di Indonesia tanaman ini menyebar hampir di seluruh wilayah. Kegunaan pepaya cukup beragam dan hampir semua bagian pepaya dapat dimanfaatkan untuk berbagai keperluan. Daun mudanya dapat digunakan sebagai sayur, getah pepaya yang banyak mengandung enzim papain yang juga dapat diolah menjadi produk perdagangan dan banyak digunakan dalam berbagai makanan, minuman dan industri farmasi. Buahnya selain digunakan untuk memenuhi kebutuhan gizi keluarga juga memiliki nilai ekonomi yang cukup tinggi (Direktorat Jenderal Hortikultura, 2005).

Pengembangan usahatani tanaman pepaya merupakan salah satu alternatif dalam penganekaragaman pertanian. Peningkatan kualitas dan kuantitas produksi pepaya dapat memberikan sumbangan yang besar terhadap pendapatan petani pepaya, perluasan kesempatan kerja dan peningkatan gizi masyarakat. Pemasaran buah pepaya juga cukup mudah, bahkan pada musim tertentu jumlah penawaran sering tidak dapat memenuhi permintaan pasar, sehingga harganya mahal. Oleh karena itu, peluang ini bisa dimanfaatkan untuk membudiyakan tanaman pepayaselain cara budidayanya juga tergolong mudah (Saparinto, dan Diana, 2011).

Perkembangan luas lahan, produksi dan produktivitas buah pepaya di Indonesia setiap tahun masih terus berusaha untuk ditingkatkan. Usaha peningkatan produksi buah pepaya tersebut sejalan dengan adanya peningkatan luas lahan. Perkembangan luas panen, produksi dan produktivitas buah pepaya di Indonesia tahun 2011 2015 mengalami fluktuasi yang cukup tajam sebagaimana yang tampak pada Gambar 1. Naik turunnya luas panen ternyata berdampak juga pada terjadinya fluktuasi produksi pepaya di Indonesia. Rata-rata produksi pepaya di Indonesia selama periode 2011-2015 mengalami penurunan sekitar 3,78\%. Berdasarkan tabel 1.2 produksi buah pepaya pada tahun 2011 produksi buah pepaya sebesar 958.251 ton. Lalu mengalami penurunan sebesar $5,42 \%$ dari tahun sebelumnya, sehingga produksi buah pepaya pada tahun 2012 menjadi sebesar 906.312 ton. 


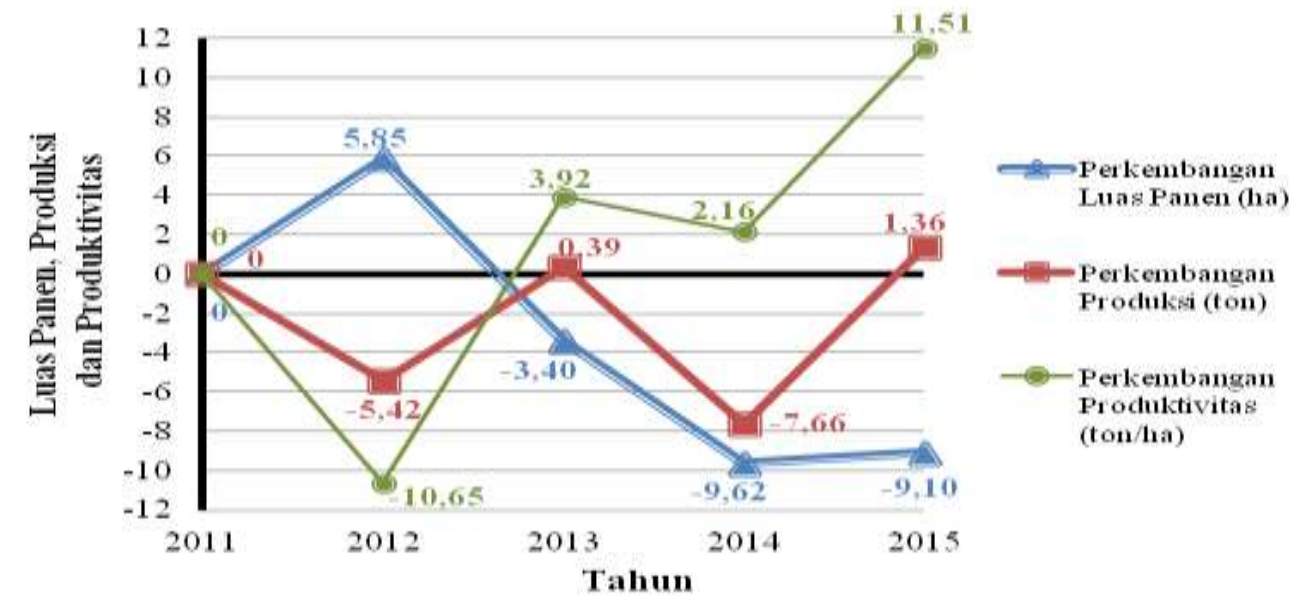

\section{Gambar 1. Perkembangan Luas Panen, Produksi dan Produktivitas Buah} Pepaya di Indonesia Tahun 2011-2015 (Sumber: BPS, 2016)

Gambar 1 di atas juga menunjukkan bahwa pada tahun 2013 secara nasional produksi pepaya kembali mengalami peningkatan sebesar $0,39 \%$ dari tahun sebelumnya yaitu sebesar 909.827 ton. Lalu pada tahun 2014 mengalami penurunan lagi sebesar $7,66 \%$ dengan produksi sebesar 840.121 ton. Hal ini dikarenakan luas panen buah pepaya yang megalami penurunan, sehingga berdampak pula pada jumlah produksi buah pepaya yang menurun. Akan tetapi, keadaan ini tidak berlangsung lama karena pada tahun berikutnya yaitu pada tahun 2015 terjadi peningkatan produksi buah pepaya sebesar $1,36 \%$.

Demikian pula produktivitas pepaya di Indonesia juga mengalami fluktuasi, dimana pada tahun 2011-2015 rata-rata produktivitasnya meningkat sebesar 1,39\% yaitu dari 86,68 ton/ha pada tahun 2011 naik menjadi 91,69 ton/ha atau meningkat sebesar 11,51\% (Direktorat Jenderal Hortikultura, 2016). Sementara itu, perkembangan produksi buah pepaya di Pulau Jawa yang terdiri dari enam provinsi antara lain: provinsi D.K.I Jakarta, Jawa Barat, Jawa Tengah, Daerah Istimewa Yogyakarta, Jawa Timur dan Banten juga mengalami fluktuasi selama periode 20112015. Pada periode tersebut terlihat bahwa yang menjadi sentra produksi pepaya berada di Propinsi Jawa Timur. Meskipun demikian produksi pepaya di Jawa Timur juga mengalami fluktuasi termasuk di Kabupaten Jember.

Kabupaten Jember merupakan kabupaten yang memiliki lahan pertanian yang cukup luas di Jawa Timur. Salah satu komoditas hortikultura yang banyak dibudidayakan di Kabupaten ini adalah pepaya. Hampir seluruh wilayah kecamatan di Kabupaten Jember mengusahakan buah pepaya. Pada Tabel 1 memberikan informasi tentang 10 besar kecamatan penghasil buah pepaya yang ada di Kabupaten Jember pada tahun 2015. 
Tabel 1. Jumlah Tanaman Menghasilkan dan Produksi Pepaya di Kabupaten Jember Menurut Kecamatan 2015

\begin{tabular}{clcc}
\hline No. & \multicolumn{1}{c}{ Kecamatan } & $\begin{array}{c}\text { Jumlah Tanaman Menghasilkan } \\
\text { (pohon) }\end{array}$ & Produksi (ton) \\
\hline 1 & Ledokombo & 350.000 & 53.985 \\
2 & Silo & 174.526 & $14.579,4$ \\
3 & Sumberjambe & 26.400 & $2.768,6$ \\
4 & Gumukmas & 23.750 & 4.703 \\
5 & Sukowono & 6.448 & 723,3 \\
6 & Sumberbaru & 6.210 & 963 \\
7 & Puger & 5.610 & 450,6 \\
8 & Ambulu & 5.232 & 905,7 \\
9 & Rambipuji & 4.618 & 649,8 \\
10 & Arjasa & 4.507 & 632,1 \\
11 & Lain-lain & 24.220 & $3.681,5$ \\
\hline
\end{tabular}

Sumber: BPS Kabupaten Jember, 2016 (diolah 2017).

Berdasarkan Tabel 1 dapat dilihat bahwa produksi buah pepaya di Kabupaten Jember adalah sebesar 84.042 ton pada tahun 2015. Produksi buah pepaya pada masing-masing Kecamatan di Kabupaten Jember berbeda-beda. Kecamatan Ledokombo merupakan sentra produksi buah pepaya di Kabupaten Jember dengan jumlah 350.000 pohon dan produksinya 53.985 ton/tahun, sehingga peneliti tertarik untuk melakukan penelitian di kecamatan tersebut. Menurut BPS Kabupaten Jember (2017) bahwa di wilayah Kecamatan Ledokombo selain pepaya, juga terdapat banyak buah alpukat, petae dan durian.

Tingkat keberhasilan produksi tanaman pepaya dibandingkan dengan jenis buah-buahan lainnya dapat ditentukan oleh produksi optimal yang dicapai oleh petani pepaya di Kecamatan Ledokombo. Tercapainya produksi yang tinggi maupun rendah dapat menjadi dugaan indikasi yang menunjukan adanya faktor-faktor risiko produksi usahatani pepaya di Kecamatan Ledokombo. Hal ini tentunya juga dapat merugikan petani karena risiko produksi akan berpengaruh terhadap hasil panen pepaya. Hasil panen yang berfluktuasi akan mengakibatkan pendapatan petani atau keuntungan usahatani pepaya juga dapat mengalami fluktuasi. Oleh karena itu, tujuan penelitian ini adalah untuk: (1) Mengidentifikasi pengaruh faktor-faktor internal dan eksternal terhadap risiko produksi usahatani pepaya; dan (2) Mengidentifikasi faktor-faktor yang mempengaruhi keuntungan usahatani pepaya.

\section{METODOLOGI PENELITIAN}

\section{Jenis dan Metode Penelitian}

Jenis penelitian yang digunakan dalam penelitian ini adalah metode deskriptif. Menurut pendapat Suryabrata 
(1983) metode deskriptif digunakan

untuk membuat pencandraan secara sistematis, faktual dan akurat mengenai fakta-fakta dan sifat-sifat populasi atau daerah tertentu. Dipilihnya metode survei karena jumlah populasi sasaran jenis kegiatan cukup banyak dan tersebar di beberapa wilayah perdesaan.

\section{Penentuan Lokasi Penelitian}

Penentuan lokasi penelitian yaitu di Kecamatan Ledokombo Kabupaten Jember dilakukan dengan cara sengaja (purposive) (Nazir, 1999 dalam Widjayanti 2010). Pemilihan lokasi penelitian di kecamatan ini berdasarkan pertimbangan bahwa kecamatan ini merupakan penghasil pepaya terbesar pertama di kabupaten tersebut, atau dapat dikatakan bahwa kecamatan ini sebagai sentra komoditas pepaya di Kabupaten Jember.

\section{Metode Pengambilan Sampel}

Berdasarkan rumus Slovin pada populasi atau jumlah petani pepaya di Kecamatan Ledokombo dari 3 desa yang telah di pilih menjadi desa sampel, yaitu berjumlah 122 petani. Penentuan jumlah sampel menggunakan rumus Slovin sebagai berikut:

$\mathrm{N}$ minimal $=n=\frac{N}{1+N(e)^{2}}$

$n=\frac{122}{1+122(0,1)^{2}}$ $n=55$

di mana:

$\mathrm{n}=$ sampel

$\mathrm{N}=$ populasi

$\mathrm{e}=$ tingkat kesalahan $(10 \%)$

Tabel 2. Sebaran Populasi dan Teknik Penentuan Sampel Penelitian

\begin{tabular}{clcc}
\hline No. & \multicolumn{1}{c}{ Desa } & Populasi & Sampel \\
\hline 1 & Ledokombo & 73 & 33 \\
2 & Lembengan & 37 & 17 \\
3 & Karangpaiton & 12 & 5 \\
\hline \multicolumn{2}{c}{ Jumlah } & $\mathbf{1 2 2}$ & $\mathbf{5 5}$ \\
\hline
\end{tabular}
(diolah 2017).

\section{Sumber dan Metode Pengumpulan Data}

Data yang digunakan dalam penelitian ini bersumber dari data primer dan data sekunder. Data primer merupakan data yang diperoleh secara langsung dari petani responden dengan melakukan wawancara yang berpedoman pada daftar pertanyaan yang telah disusun sebelumnya. Adapun teknik pengumpulan data dilakukan dengan cara melalui teknik in-depth interview (Sugiyono, 2010). Data sekunder merupakan data yang diperoleh dari dinas atau instansi yang berhubungan dengan penelitian ini. Data-data tersebut dikumpulkan dengan cara mendatangi dinas atau instansi yang terkait dan menggali data yang berhubungan dengan penelitian.

\section{Metode Analisis Data}

Metode analisis data yang digunakan untuk menguji hipotesis dalam penelitian ini adalah:

1. Untuk menjawab hipotesis pertama tentang faktor-faktor internal dan 
eksternal yang berpengaruh terhadap risiko produksi usahatani pepaya. Hubungan antara variable $\mathrm{X}$ dan $\mathrm{Y}$ tersebut secara matematik dirumuskan sebagai berikut (Sutiarso, 2010).

$$
\boldsymbol{Y}=\boldsymbol{\beta}_{\mathrm{O}} \boldsymbol{X}_{\mathbf{1}_{i}}^{\beta_{1}} \boldsymbol{X}_{2_{i}}^{\beta_{2}}, \ldots, \boldsymbol{X}_{k}^{\beta_{k}} e^{d D+\delta_{i}}
$$

Diduga faktor-faktor yang berpengaruh terhadap produksi usahatani pepaya adalah bibit, pupuk anorganik, pupuk organik, pupuk buah, tenaga kerja, pestisida padat, pestisida cair dan musim. Secara sistematik, persamaan taksiran fungsi produksi dengan model regresi adalah

$Y=b_{0} X_{1}^{b_{1}} X_{21}^{b_{2}} X_{3}^{b_{3}} X_{4}^{b_{4}} X_{5}^{b_{5}} X_{6}^{b_{6}} X_{7}^{b_{7}} X_{8}^{b_{8}} e^{d D+\delta_{i}}$

Adapun fungsi produksi rata-rata dan fungsi variance produktivitas pepaya sebagai berikut:

a. Fungsi Produksi Rata-rata:

$L_{n} Y_{i}=\beta_{0}+\beta_{1} \operatorname{LnX} X_{1 i}+\beta_{2} \operatorname{LnX} X_{2 i}+\beta_{3} \operatorname{LnX} 3 i+\beta_{4} \operatorname{LnX} 4 i+\beta_{5} \operatorname{LnX} X_{5 i}+\beta_{6} \operatorname{LnX} 6 i$ $+\beta_{7} \operatorname{LnX} 7 i+\beta_{8} D_{1 i}+\varepsilon$

b. Fungsi Variance Produktivitas:

${ }^{\mathrm{Ln} \sigma}{ }_{\mathrm{Yi}}^{2}=\theta_{0}+\theta_{1} \mathrm{LnX}_{1 \mathrm{i}}+\theta_{2} \mathrm{LnX}_{2 \mathrm{i}}+\theta_{3} \mathrm{LnX}_{3 \mathrm{i}}+\theta_{4} \mathrm{LnX}_{4 \mathrm{i}}+\theta_{5} \mathrm{LnX}_{5 \mathrm{i}}+\theta_{6} \mathrm{LnX}_{6 \mathrm{i}}$ $+\theta_{7} \operatorname{LnX}_{7 \mathrm{i}}+\theta_{8} \mathrm{LnD}_{1 \mathrm{i}}+\varepsilon$

c. Variance Produktivitas:

$$
\sigma_{Y i}^{2}=\left(Y_{i}-\hat{Y}_{i}\right)^{2}
$$

di mana:

$Y=$ produksi pepaya $(\mathrm{ku})$

$\hat{Y}=$ nilai penduga

$X_{1}=$ jumlah bibit per musim tanam (pohon)

$X_{2}=$ jumlah pupuk anorganik per musim tanam $(\mathrm{kg})$

$X_{3}=$ jumlah pupuk organik per musim tanam $(\mathrm{kg})$
$X_{4}=$ jumlah pupuk buah per musim tanam $(\mathrm{kg})$

$X_{5}=$ jumlah tenaga kerja per musim tanam (HOK)

$X_{6}=$ jumlah pestisida padat per musim tanam $(\mathrm{kg})$

$X_{7}=$ jumlah pestisida cair per musim tanam (1)

$D=$ dummy musim $(\mathrm{D}=0$ jika musim hujan dan $\mathrm{D}=1$ jika musim kemarau)

$\varepsilon=$ error

$i=$ petani responden

$\sigma_{Y i}^{2}=$ variance produktivitas pepaya

$b_{0}, \theta_{0}=$ konstanta

$b_{1}, b_{2}, \ldots, b_{7}=$ koefisien parameter dugaan $X_{1}, X_{2}, \ldots, X_{7}$

$\theta_{1}, \theta_{2}, \ldots, \theta_{7}=$ koefisien parameter dugaan $X_{1}, X_{2}, \ldots, X_{7}$

2. Guna menjawab hipotesis yang kedua faktor-faktor yang mempengaruhi keuntungan usahatani pepaya, digunakan pendekatan analisis regresi berganda, dengan asumsi bahwa bentuk hubungan antara variabel $(\mathrm{X})$ dengan variabel (Y) merupakan fungsi produksi Cobb-Douglas. Hubungan antara variabel $\mathrm{X}$ dan $\mathrm{Y}$ tersebut, secara matematik dirumuskan sebagai berikut (Sutiarso, 2016):

$$
Y_{i}=\beta_{0} X_{1_{i}}^{\beta_{1}} X_{2_{i}}^{\beta_{2}} \ldots X_{k_{i}}^{\beta_{k}} e^{\delta_{i}}
$$

Faktor-faktor yang diduga berpengaruh terhadap keuntungan adalah harga output, jumlah produksi dan biaya produksi. Secara matematis, persamaan 
taksiran fungsi keuntungan dengan model regresi adalah:

$$
\hat{Y}=b_{0} X_{1}^{b_{1}} X_{2}^{b_{2}} X_{3}^{b_{3}} X_{4}^{b_{4}} X_{5}^{b_{5}}
$$

di mana:

$\hat{Y}=$ keuntungan usahatani pepaya

(Rp)

$X_{1}=$ harga output $(\mathrm{Rp})$

$X_{2}=$ produksi $(\mathrm{kg})$

$X_{3}=$ biaya tenaga kerja $(\mathrm{Rp})$

$X_{4}=$ biaya saprodi $(\mathrm{Rp})$

$X_{5}=$ biaya lahan $(\mathrm{Rp})$

$b_{0}=$ konstanta

$b=$ koefisien regresi variabel

bebas

\section{HASIL DAN PEMBAHASAN}

\section{Analisis Faktor-faktor yang Mempengaruhi Produktivitas Pepaya di Kecamatan Ledokombo Kabupaten Jember}

Hasil analisis regresi terhadap fungsi produksi rata-rata (produktivitas) usahatani pepaya di daerah penelitian sebagaimana pada Tabel 3 menunjukkan bahwa nilai F- hitung lebih besar daripada nilai F-tabel $(2,274>2,21)$ dan nilai signifikansi $0,004<$ 0,05 , sehingga hipotesis diterima atau taraf nyata $\alpha 10 \%$. Hal ini dapat dijelaskan bahwa faktor-faktor produksi yang digunakan secara bersama-sama berpengaruh nyata terhadap produksi pepaya. Selanjutnya jika dilihat dari nilai koefisien determinasi $\left(R^{2}\right)$ yaitu sebesar 0,283 menunjukkan bahwa variabel bebas dimasukkan ke dalam model dapat mengidentifikasi-kan variasi variabel dependen (produktivitas) secara baik sekitar $28,3 \%$, sedangkan $71,7 \%$ yang dijelaskan oleh faktor lain yang tidak dimasukkan ke dalam model, diantaranya umur petani, tingkat pendidikan petani dan pengalaman berusahatani.

Tabel 3. Hasil Analisis Regresi Fungsi Produksi Rata-rata Usahatani Pepaya di Kecamatan Ledokombo Kabupaten Jember Tahun 2017

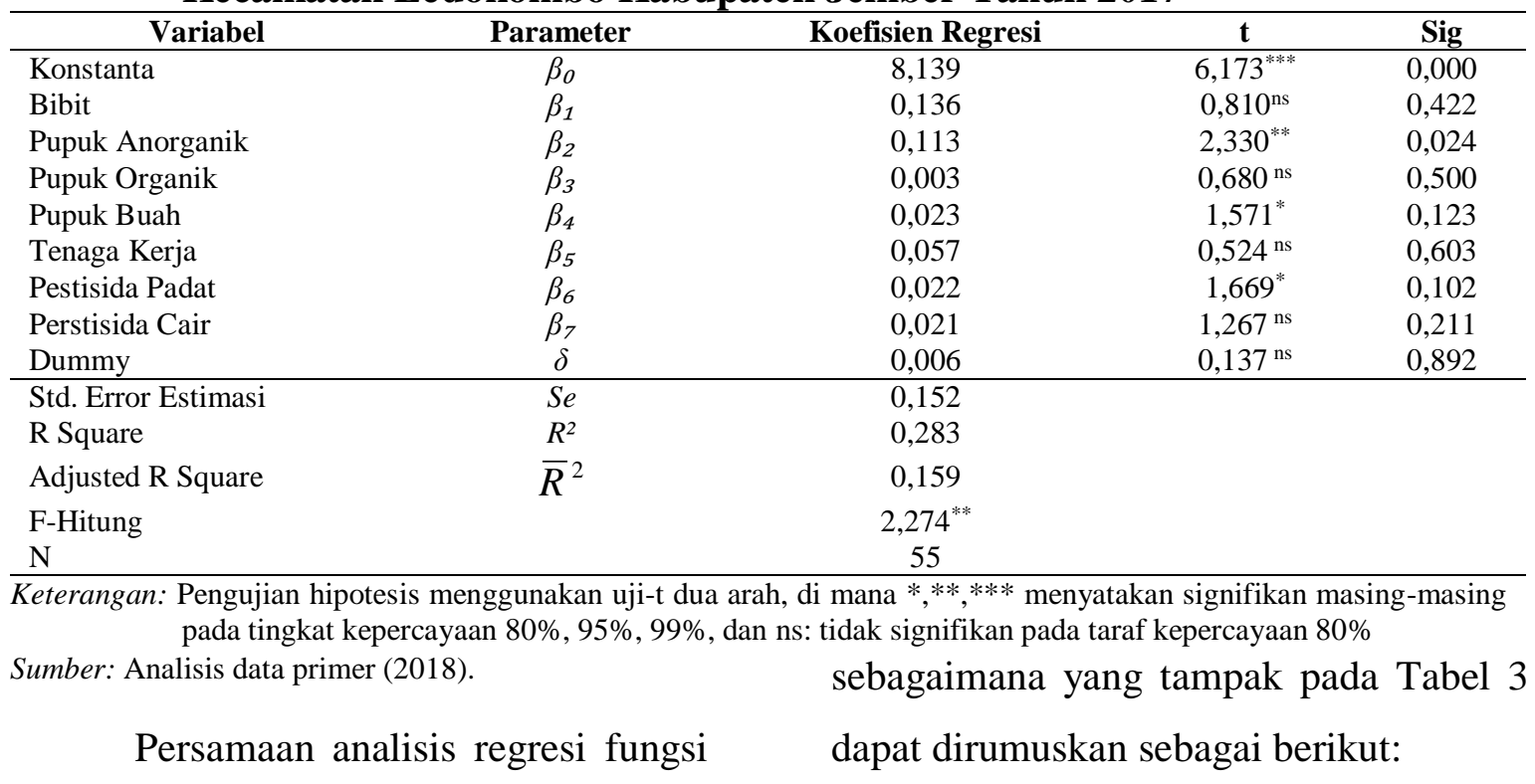

produksi rata-rata usahatani pepaya 
$\ln Y=8,139+0,136 \ln X_{1}+0,113 \ln X_{2}+0,003 \ln X_{3}+0,023 \ln X_{4}+0,057 \ln X_{5}$ $+0,022 \ln X_{6}+0,021 \ln { }_{7}+0,006 D \ln e$

Pada musim hujan $\mathrm{D}=0$, sehingga persamaan menjadi:

$\ln Y=8,139+0,136 \ln X_{1}+0,113 \ln X_{2}+0,003 \ln X_{3}+0,023 \ln X_{4}+0,057 \ln X_{5}$ $+0,022 \ln X_{6}+0,021 n X_{7}+(0 x 0,006)$

Pada musim kemarau $\mathrm{D}=1$ :

$\ln Y=8,139+0,136 \ln X_{1}+0,113 \ln X_{2}+0,003 \ln X_{3}+0,023 \ln X_{4}+0,057 \ln X_{5}$ $+0,022 \ln X_{6}+0,021 \ln X_{7}+(1 x 0,006)$

$\ln Y=8,145+0,136 \ln X_{1}+0,113 \ln X_{2}+0,003 \ln X_{3}+0,023 \ln X_{4}+0,057 \ln X_{5}$ $+0,022 \ln X_{6}+0,021 n X_{7}$

Secara matematik dapat diformulasikan dengan fungsi produksi rata-rata CobbDouglas sebagai berikut:

Pada musim hujan:

$Y=3.425,49 X_{1}{ }^{0,136} X_{2}{ }^{0,113} X_{3}{ }^{0,003} X_{4}{ }^{0,023} X_{5}{ }^{0,057} X_{6}{ }^{0,022} X_{7}{ }^{0,021}$

Pada musim kemarau:

$Y=3.446,11 X_{1}^{0,136} X_{2}{ }^{0,113} X_{3}{ }^{0,003} x_{4}{ }^{0,023} X_{5}{ }^{0,057} X_{6}{ }^{0,022} X_{7}{ }^{0,021}$

Secara parsial hasil analisis regresi beberapa faktor yang berpengaruh terhadap produktivitas usahatani pepaya di daerah penilitian dapat dibahas sebagai berikut:

1. Bibit $\left(\mathrm{X}_{1}\right)$

Faktor penggunaan bibit berpengaruh positif dan tidak signifikan terhadap produktivitas pepaya pada taraf uji 20\%. Koefisien regresi dugaan menunjukkan nilai positif, sehingga penambahan bibit akan mengakibatkan produktivitas pepaya meningkat. Nilai koefisien bibit yaitu sebesar 0,136 yang artinya setiap penambahan jumlah bibit sebesar 1\%, akan meningkatkan produktivitas sebesar $0,136 \%$ dengan asumsi variabel produktivitas lainnya dianggap tetap.

2. Pupuk Anorganik $\left(X_{2}\right)$

Faktor penggunaan pupuk anorganik berpengaruh signifikan terhadap produkivitas pepaya pada taraf uji 5\%. Koefisien regresi dugaan menunjukkan nilai positif, yang artinya setiap penambahan pupuk anorganik akan mengakibatkan produktivitas pepaya juga meningkat. Nilai koefisien regresi pupuk anorganik adalah 0,113, maka penambahan penggunaan pupuk anorganik sebesar $1 \%$ dapat meningkatkan produktivitas pepaya sebesar $0,113 \%$ dengan asumsi variabel produksi lainnya dianggap tetap.

3. Pupuk Organik $\left(X_{3}\right)$

Faktor penggunaan pupuk organik berpengaruh tidak signifikan terhadap produktivitas pepaya pada taraf uji $20 \%$. Koefisien regresi dugaan menunjukkan nilai positif, sehingga penambahan pupuk organik akan mengakibatkan produktivitas pepaya juga meningkat. Nilai koefisien pupuk organik yaitu sebesar 0,003, yang artinya setiap penambahan jumlah pupuk organik sebesar $1 \%$ akan meningkatkan produktivitas sebesar $0,006 \%$ dengan 
asumsi variabel produksi lainnya dianggap tetap.

4. Pupuk Buah $\left(\mathrm{X}_{4}\right)$

Faktor penggunaan pupuk buah berpengaruh signifikan terhadap produktivitas pepaya pada taraf uji $20 \%$. Koefisien regresi dugaan menunjukkan nilai positif, artinya penambahan pupuk buah akan mengakibatkan produktivitas juga meningkat. Nilai koefisien regresi pestisida adalah 0,023, maka setiap penambahan penggunaan pupuk buah sebesar $1 \%$ dapat meningkatkan produktivitas pepaya sebesar $0,023 \%$ dengan asumsi variabel produksi lainnya dianggap tetap.

5. Tenaga Kerja $\left(\mathrm{X}_{5}\right)$

Faktor penggunaan tenaga kerja berpengaruh positif, akan tetapi secara statistik tidak signifikan terhadap produktivitas pepaya pada taraf uji $20 \%$. Artinya, penambahan tenaga kerja akan meningkatkan produktivitas usahatani pepaya. Nilai koefisien regresi tenaga kerja adalah 0,057, maka setiap penambahan penggunaan tenaga kerja sebesar $1 \%$ dapat meningkatkan produktivitas pepaya sebesar $0,057 \%$ dengan asumsi variabel produksi lainnya dianggap tetap.

6. Pestisida Padat $\left(\mathrm{X}_{6}\right)$

Faktor penggunaan pestisida padat berpengaruh signifikan terhadap produkivitas pepaya pada taraf uji $20 \%$.
Koefisien regresi dugaan menunjukkan nilai positif, artinya penambahan pestisida padat akan mengakibatkan produktivitas pepaya juga meningkat. Nilai koefisien regresi pestisida padat adalah 0,022, maka setiap penambahan penggunaan pestisida padat sebesar $1 \%$ dapat meningkatkan produktivitas pepaya sebesar $0,022 \%$ dengan asumsi variabel produksi lainnya dianggap tetap.

\section{Pestisida Cair $\left(\mathrm{X}_{7}\right)$}

Faktor pestisida cair berpengaruh positif, akan tetapi secara statistik tidak signifikan terhadap produkivitas pepaya pada taraf uji 20\%. Koefisien regresi dugaan menunjukkan nilai positif, artinya penambahan pestisida cair akan mengakibatkan produktivitas pepaya juga meningkat. Nilai koefisien regresi pestisida cair adalah 0,030, maka setiap penambahan penggunaan pestisida cair sebesar $1 \%$ dapat meningkatkan produktivitas pepaya sebesar $0,030 \%$ dengan asumsi faktor produksi lainnya dianggap tetap.

\section{Musim $(D)$}

Faktor musim berpengaruh tidak signifikan terhadap produktivitas pepaya pada taraf uji 20\%. Koefisien regresi dugaan menunjukkan nilai positif. Hal ini berarti bahwa produktivitas pepaya pada musim kemarau lebih rendah daripada musim hujan. Nilai koefisien regresi musim adalah 0,006, maka penanaman 
pepaya pada musim hujan akan meningkatkan nilai produktivitas pepaya sebesar $0,006 \%$ dengan asumsi faktor produksi lainnya dianggap tetap.

\section{Analisis $\quad$ Faktor-faktor yang Mempengaruhi Risiko Produksi Pepaya di Kecamatan Ledokombo Kabupaten Jember}

Hasil pendugaan fungsi variance produktivitas diperoleh nilai F-hitung lebih kecil daripada nilai F-tabel $(0,312<$ 1,85) dan nilai signifikansi $0,96>0,10$, sehingga dapat dijelaskan bahwa faktorfaktor produktivitas yang digunakan secara bersama-sama berpengaruh tidak nyata terhadap variance produktivitas usahatani pepaya (Tabel 4). Sementara jika ditinjau dari nilai koefisien determinasi $\left(\mathrm{R}^{2}\right)$ yaitu sebesar 0,051 menunjukkan bahwa variabel bebas dimasukkan ke dalam model dapat mengidentifikasikan variasi variabel dependen (variance produktivitas) sebesar $5,1 \%$, sedangkan $94,9 \%$ yang dijelaskan oleh faktor lain yang tidak dimasukkan ke dalam model diantaranya manajerial, serangan hama dan penyakit

Tabel 4. Hasil Analisis Regresi Fungsi Variance Produktivitas Usahatani Pepaya di Kecamatan Ledokombo Kabupaten Jember Tahun 2017

\begin{tabular}{lcccc}
\hline \multicolumn{1}{c}{ Variabel } & Parameter & Koefisien Regresi & T & Sig \\
\hline Konstanta & $\beta_{0}$ & 0,163 & $0,369^{\mathrm{ns}}$ & 0714 \\
Bibit & $\beta_{1}$ & $-0,041$ & $-0,708^{\mathrm{ns}}$ & 0,482 \\
Pupuk Anorganik & $\beta_{2}$ & 0,001 & $0,068^{\mathrm{ns}}$ & 0,947 \\
Pupuk Organik & $\beta_{3}$ & 0,000 & $-0,253^{\mathrm{ns}}$ & 0,801 \\
Pupuk Buah & $\beta_{4}$ & $-0,002$ & $-0,663^{\mathrm{ns}}$ & 0,511 \\
Tenaga Kerja & $\beta_{5}$ & 0,034 & $0,946^{\mathrm{ns}}$ & 0,349 \\
Pestisida Padat & $\beta_{6}$ & $-0,001$ & $-0,280^{\mathrm{ns}}$ & 0,781 \\
Perstisida Cair & $\beta_{7}$ & 0,000 & $0,005^{\mathrm{ns}}$ & 0,996 \\
Dummy & 4 & 0,004 & $0,298^{\mathrm{ns}}$ & 0,767 \\
\hline Std. Error Estimasi & $S e$ & 0,049 & & \\
R Square & $R^{2}$ & 0,051 & & \\
Adjusted R Square & $\bar{R}^{2}$ & $-0,113$ & & \\
F-Hitung & & $0,312^{\mathrm{ns}}$ & & \\
$\mathrm{N}$ & & 55 & & \\
\hline
\end{tabular}

Keterangan: Pengujian hipotesis menggunakan uji-t dua arah, di mana ns: tidak signifikan pada taraf kepercayaan $90 \%$ Sumber: Analisis data primer (2018).

Pada musim hujan $\mathrm{D}=0$, sehingga

Berdasarkan hasil pendugaan fungsi variance produktivitas pada Tabel 4, maka fungsi variance produktivitas persamaan menjadi:

$\ln \sigma_{Y i}^{2}=0,163-0,041 \ln X_{1}+0,001 \ln X_{2}+0,000 \ln X_{3}-0,002 \ln X_{4}+0,034 \ln X_{5}$ $-0,001 \ln X_{6}+0,000 n X_{7}+(0 x 0,004)$ pepaya dapat diduga dengan persamaan sebagai berikut:

$\ln \sigma_{Y i}^{2}=0,163-0,041 \ln X_{1}+0,001 \ln X_{2}+0,000 \ln X_{3}-0,002 \ln X_{4}+0,034 \ln X_{5}$ $-0,001 \ln X_{6}+0,000 \ln X_{7}+0,004 D \ln e$

Pada musim kemarau $\mathrm{D}=1$ :

$\stackrel{2}{2} \sigma_{Y i}=0,163-0,041 \ln X_{1}+0,001 \ln X_{2}+0,000 \ln X_{3}-0,002 \ln X_{4}+0,034 \ln X_{5}$ $-0,001 \ln X_{6}+0,000 \ln X_{7}+(1 x 0,004)$ 
$\ln \sigma_{Y_{i}}^{2}=0,167-0,041 \ln X_{1}+0,001 \ln X_{2}+0,000 \ln X_{3}-0,002 \ln X_{4}+0,034 \ln X_{5}$ $-0,001 \ln X_{6}+0,000 \ln X_{7}$

Secara matematik dapat diformulasikan dengan fungsi varian produktivitas Cobb-Douglas sebagai berikut:

Pada musim hujan:

$\sigma_{Y i}^{2}=1,177 X_{1}{ }^{-0,041} X_{2}{ }^{0,001} X_{3}{ }^{0,000} X_{4}{ }^{-0,002} X_{5}{ }^{0,034} X_{6}{ }^{-0,001} X_{7}{ }^{0,000}$

Pada musim kemarau:

$\sigma_{Y i}^{2}=1,182 X_{1}{ }^{-0,041} X_{2}{ }^{0,001} X_{3}{ }^{0,000} X_{4}{ }^{-0,002} X_{5}{ }^{0,034} X_{6}{ }^{-0,001} X_{7}{ }^{0,000}$

Secara parsial pengaruh masingmasing faktor produktivitas terhadap variance produktivitas pepaya dijelaskan sebagai berikut:

1. Bibit $\left(\mathrm{X}_{1}\right)$

Faktor penggunaan

bibit berpengaruh tidak signifikan terhadap variance produktivitas pepaya pada taraf uji 20\%. Koefisien regresi dugaan menunjukkan nilai negatif, sehingga penambahan bibit akan menurunkan variance produktivitas pepaya. Nilai koefisien bibit yaitu sebesar -0,041, yang artinya setiap penambahan jumlah bibit sebesar $1 \%$ akan menurunkan variance produktivitas sebesar $0,041 \%$ dengan asumsi variabel produksi lainnya dianggap tetap.

2. Pupuk Anorganik $\left(\mathrm{X}_{2}\right)$

Faktor penggunaan pupuk anorganik berpengaruh tidak signifikan terhadap variance produktivitas pepaya pada taraf uji $20 \%$. Koefisien regresi dugaan menunjukkan nilai positif, sehingga penambahan pupuk anorganik akan mengakibatkan peningkatan variance produktivitas pepaya. Nilai koefisien pupuk anorganik yaitu sebesar 0,001, yang artinya setiap penambahan jumlah pupuk anorganik sebesar $1 \%$ akan meningkatkan variance produktivitas sebesar $0,001 \%$ dengan asumsi variabel produktivitas lainnya dianggap tetap.

\section{Pupuk Organik $\left(\mathrm{X}_{3}\right)$}

Faktor penggunaan pupuk organik berpengaruh tidak signifikan terhadap variance produktivitas pepaya pada taraf uji 20\%. Koefisien regresi dugaan menunjukkan nilai positif, sehingga penambahan pupuk organik akan mengakibatkan peningkatan variance produktivitas pepaya. Nilai koefisien pupuk organik yaitu sebesar 0,000 , yang artinya setiap penambahan jumlah pupuk organik sebesar $1 \%$ akan menurunkan variance produktivitas sebesar $0,000 \%$ dengan asumsi variabel produktivitas lainnya dianggap tetap.

4. Pupuk Buah $\left(\mathrm{X}_{4}\right)$

Faktor penggunaan pupuk buah berpengaruh tidak signifikan terhadap variance produktivitas pepaya pada taraf uji 20\%. Koefisien regresi dugaan menunjukkan nilai negatif, sehingga semakin banyak pupuk buah yang digunakan dalam proses produksi, maka 
variance produktivitas pepaya semakin berkurang. Nilai koefisien pupuk buah yaitu sebesar $-0,002$, artinya penambahan jumlah pupuk buah sebesar 1\%, akan menurunkan variance produktivitas sebesar $0,002 \%$ dengan asumsi variabel produktivitas lainnya dianggap tetap.

\section{Tenaga Kerja $\left(\mathrm{X}_{5}\right)$}

Faktor penggunaan tenaga kerja berpengaruh tidak signifikan terhadap variance produktivitas pepaya pada taraf uji $20 \%$. Koefisien regresi dugaan menunjukkan nilai positif, sehingga semakin banyak tenaga kerja yang digunakan dalam proses produksi, maka variance produktivitas pepaya semakin meningkat. Nilai koefisien tenaga kerja yaitu sebesar 0,034, artinya penambahan jumlah tenaga kerja sebesar $1 \%$ akan meningkatkan variance produktivitas sebesar $0,034 \%$ dengan asumsi variabel produktivitas lainnya dianggap tetap.

6. Pestisida Padat $\left(\mathrm{X}_{6}\right)$

Faktor penggunaan pestisida padat berpengaruh tidak signifikan terhadap variance produktivitas pepaya pada taraf uji $20 \%$. Koefisien regresi dugaan menunjukkan nilai negatif, sehingga semakin banyak pestisida padat yang digunakan dalam proses produksi, maka variance produktivitas pepaya semakin menurun. Nilai koefisien pestisida padat yaitu sebesar $-0,001$, artinya penambahan jumlah pestisida padat sebesar $1 \%$ akan menurunkan variance produktivitas sebesar $0,001 \%$ dengan asumsi variabel produktivitas lainnya dianggap tetap.

\section{Pestisida Cair $\left(\mathrm{X}_{7}\right)$}

Faktor penggunaan pestisida cair berpengaruh tidak signifikan terhadap variance produktivitas pepaya pada taraf uji $20 \%$. Koefisien regresi dugaan menunjukkan nilai positif, sehingga semakin banyak pestisida cair yang digunakan dalam proses produksi, maka variance produktivitas pepaya semakin meningkat. Nilai koefisien pestisida cair yaitu sebesar 0,000, artinya penambahan jumlah pestisida cair sebesar $1 \%$ akan meningkatkan variance produktivitas sebesar $0,000 \%$ dengan asumsi variabel produktivitas lainnya dianggap tetap.

\section{8. $\operatorname{Musim}(D)$}

Faktor musim berpengaruh tidak signifikan terhadap variance produktivitas pepaya pada taraf uji $20 \%$. Koefisien regresi dugaan menunjukkan nilai positif, yaitu sebesar 0,004 , hal ini berarti bahwa variance produktivitas pepaya pada musim kemarau lebih tinggi daripada musim hujan. Petani yang menanam pepaya pada musim kemarau lebih berisiko daripada petani yang menanam pada musim hujan.

\section{KESIMPULAN}

Faktor-faktor yang berpengaruh tidak signifikan terhadap risiko produksi 
pepaya adalah bibit, pupuk anorganik, pupuk organik, pupuk buah, tenaga kerja, pestisida padat, pestisida cair dan musim. Penggunaan faktor risiko produksi pupuk anorganik, tenaga kerja, pestisida padat, pestisida cair dan musim dapat meningkatkan risiko produksi, di lain sisi penggunaan bibit, pupuk organik dan pupuk buah dapat menurunkan risiko produksi, tetapi berpengaruh tidak nyata terhadap risiko produksi usahatani pepaya di Kecamatan Ledokombo Kabupaten Jember. Selanjutnya faktor produksi, harga jual, biaya tenaga kerja, biaya saprodi dan biaya lahan berpengaruh secara signifikan, sedangkan faktor musim berpengaruh tidak signifikan terhadap keuntungan usahatani pepaya di Kecamatan Ledokombo Kabupaten Jember.

\section{DAFTAR PUSTAKA}

Biro Pusat Statistik, 2016. Perkembangan

Luas Panen, Produksi dan Produktivitas Buah Pepaya di Indonesia Tahun 2011-2015. Jakarta.

BPS Kabupaten Jember, 2016. Jember Dalam Angka 2016. Badan Pusat Statistik Kabupaten Jember. Jember.

Direktorat Jenderal Hortikultura, 2005. Kinerja Pembangunan Sistem dan Usaha Agribisnis Hortikultura . Departemen Pertanian. Direktorat Jenderal Bina Produksi Hortikultura. Jakarta.
Direktorat Jenderal Hortikultura, 2016. Laporan Kinerja Direktorat Jenderal Hortikultura TA. 2016. Kementerian Pertanian Republik Indonesia Tahun 2017. Jakarta.

Nazir, M., 1999. Metode Penelitian. Jakarta: Ghalia.

Saparinto C. dan Diana H., 2011. Bahan Tambahan Pangan. Yogyakarta: Petra Christian University -Press.

Soekartawi, 1994. Agribisnis Teori dan Aplikasinya. Rajawali Press. Jakarta.

Sugiyono, 2010. Metode Penelitian Pendidikan Pendekatan Kuantitatif, kualitatif, dan R\&D. Bandung: Alfabeta.

Suryabrata, S., 1983. Metodologi Penelitian. Jakarta: CV. Rajawala.

Sutiarso, E. 2016. Analisis Regresi Sederhana. Jurusan Sosial Ekonomi Pertanian, Fakultas Pertanian, Universitas Muhammadiyah Jember, Jember.

UPTD Pertanian Kecamatan Ledokombo Kabupaten Jember, 2017. Laporan Kinerja Sektor Pertanian Di Kecamatan Ledokombo Kabupaten Jember.

Wardani, L. 2014. Populasi dan Sampel. https://lauraerawardani.blogspot.co.i d. Diakses pada tanggal 17 Februari 2017.

Widjayanti, F. N. 2010. Karakteristik Komoditas Sub Sektor Pertanian di Wilayah Jalur Lintas Selatan (JLS) Kabupaten Jember. Jember. Jurnal Universitas Muhammadiyah Jember. 